\title{
Pyrometallurgy and electrometallurgy of rare earths - Part A: Analysis of metallothermic reduction and its variants
}

\author{
Muhammad Musaddique Ali Rafique \\ Eastern Engineering Solutions Inc., Cambridge, MA 02139 \\ E: ali.rafique@easternengineeringcambridge.onmicrosoft.com
}

\begin{abstract}
Rare earths are classified as most important and critical material for US economy and defense by Congress and a mandate has been set to increase their in-house production, domestic resource utilization and decrease reliance on foreign resources and reserves. They are widely available in earth crust as ore (bastnaesite $(\mathrm{La}, \mathrm{Ce}) \mathrm{FCO}_{3}$, monazite, $(\mathrm{Ce}, \mathrm{La}, \mathrm{Y}, \mathrm{Th}) \mathrm{PO}_{4}$, and xenotime, $\mathrm{YPO}_{4}$ ), but their so-called economic reserves are sparsely located geographically. They may be produced by various means such as beneficiation (physical, chemical, mechanical, or electrical), reduction (direct or indirect), electrolysis (of aqueous or molten / fused single or mixed salt systems) at high temperature or hydrometallurgy. Out of these, direct reduction also known as metallothermic reduction (La and Ca reduction) is mostly utilized. Its variant, high temperature electrowinning of fused salts is also practiced widely. These processes are material and application specific. In this study, author will employ thermodynamics (Ellingham diagrams, free energy of formation, reduction potential, Nernst equation, Pourbaix $\left(E_{h}-p H\right)$ diagrams, E-pO-2 diagrams), kinetics and energetic of a chemical reaction (chemical metallurgy) to reduce rare earth oxide / salt to rare earth metals (REO/RES - REM). It is shown that materials and energy requirement vary greatly depending on type of mineral ore, production facility, and beneficiation / mineral processing method selected. Aim is to reduce dependence on coal deposits. It is anticipated this route will be able to produce rare earths with $>35 \%$ yield and $>98 \%$ purity which be described in subsequent studies and patents.
\end{abstract}

Keywords: metallothermy, thermodynamics, Ellingham diagrams, Nernst equation, Pourbaix ( $\left.E_{h}-\mathrm{pH}\right)$ diagrams, E-pO-2 diagrams 
Page 2 of 14

\section{Introduction}

Most common rare earth ores are bastnaesite ( $\mathrm{La}, \mathrm{Ce}) \mathrm{FCO}_{3}$, monazite, (Ce, La, Y, Th) $\mathrm{PO}_{4}$, xenotime, $\mathrm{YPO}_{4}$, lon adsorbed clays, and Eudialyte. The minimum rare earth oxide (REO) grades of traditional rare earth minerals (bastnaesite, monazite, Xenotime) and non-traditional minerals such as ionadsorbed for industrial mining are about $1.5 \%-2.0 \%$ and $0.06 \%-0.15 \%$, respectively. This suggests, rare earth mineral deposit with concentrations less than these cannot be exploited economically and cannot be designated as economic deposit no matter how large the reserve. The mineralogy of valuable element determines the recovery method. A significant number and amount of traditional rare earth minerals can be beneficiated by physical methods due to existence of physical property differences (i.e., size, density, surface chemistry, magnetics, and electrostatics) between rare earths and gangue minerals. Ion adsorbed minerals cannot be concentrated using physical beneficiation process and thus requires direct treatment using hydrometallurgy methods. They may occur naturally or as acid mine drainage (AMD) (phosphogypsum and Uranium mines), coal and coal by products. Common usage (Alloying elements in superalloys, battery materials, permanent magnets, fluorescent lamps, storage, and memory devices.

\section{Classification of rare earth elements}

Rare earth elements may be classified in different ways [1-7]. REE can be divided into critical ( $\mathrm{Nd}$, $\mathrm{Eu}, \mathrm{Tb}, \mathrm{Dy}, \mathrm{Y}$, and $\mathrm{Er}$ ), uncritical ( $\mathrm{La}, \mathrm{Pr}, \mathrm{Sm}$ and $\mathrm{Gd}$ ) and excessive (Ce, Ho, Tm, Yb and Lu) groups according to their demand and supply relationship of individual REEs [1]. Also, according to the atomic number difference, the REE can be divided into Ce group or light REEs (Sc, LA, Ce, Pr, Nd, $\mathrm{Pm}, \mathrm{Sm}, \mathrm{Eu}, \mathrm{Gd}$ ) and yttrium group or heavy REEs (Y, Tb, Dy, Ho, Er, Tm, Yb, Lu) [2, 5]. Another method of classification is based on solubility of rare earth salt [7]. The insoluble cerium group or light REE (Sc, La, Ce, Pr, Nd, Sm), slightly soluble terbium group or middle REE (Eu, Gd, Tb, Dy) and soluble ytterbium group or heavy REE (Ho, Er, Tm, Yb, Lu, Y).

\section{Processing}

Processing of rare earth may be classified on the basis of origin (deposit or recyclable materials (e.g scrap)), type of ore, its beneficiation, pretreatment, and choice of technology. Based on this these may be (a) conventional calcination and roasting $[8,9]$ in which ore is treated with an acid and then heated at an elevated temperature to remove volatiles and promote chemical reactions assisting formation of final product, (b) metallothermic reduction, (c) electrowinning and (d) hydrometallurgy. These are described in detail below,

\section{Metallothermic reduction (Pyrometallurgy)}

Metallothermic reduction may be classified into two categories. (a) Lanthanum reduction: High temperature - high vacuum lanthanum (La) reduction of rare earth oxides (REO) to metal vapor 
and deposition of this vapor as pure solid metal on cool surface and (b) Calcium reduction: high temperature calcium reduction of rare earth fluorides (REF) to molten metal. Method a does not require preparation and handling of hazardous fluoride compound but it can only be used for metals with very high vapor pressures. It is used to produce $\mathrm{Sm}, \mathrm{Eu}, \mathrm{Tm}$ and $\mathrm{Yb}$. Lanthanum is used for reduction because it; (a) is a strong reductant and (b) has a low vapor pressure, thus does not contaminate the reduction / deposition product. Method $\mathbf{b}$ is used for all other rare earth metals, often in competition with electrowinning. Note: $\mathrm{C}$ and $\mathrm{H}$ are never used for rare earth metal reduction. Their reduction power is too low.

\subsection{Lanthanum reduction}

Metal mostly produced by lanthanum reduction is Samarium. It is widely used in samarium cobalt permanent magnets, but it cannot be electrowon because of its high vapor pressure. It is produced by two step lanthanothermic reduction followed by vapor deposition process. The reaction is as follows [10],

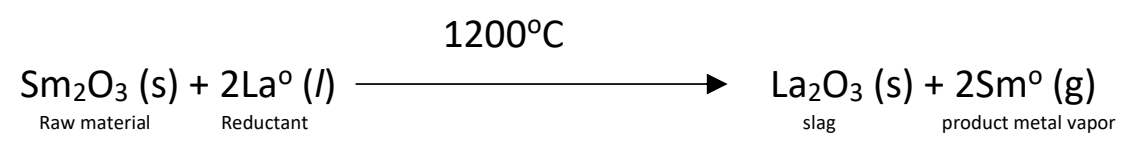

\subsubsection{Thermodynamics}

The Gibbs free energy change for the reaction 1 is +45 megajoules / kg-mole of $\mathrm{Sm}_{2} \mathrm{O}_{3}[11]$. This free energy change is related to above reaction's equilibrium quantities by the equations:

and

$$
K_{E}=\frac{a_{L a_{2} O_{3}(s)}^{E} x\left(a_{S m^{o}(g)}^{E}\right)^{2}}{a_{S m_{2} O_{3}(s)}^{E} x\left(a_{L a^{o}(l)}^{E}\right)^{2}}
$$

$$
K_{E}=e^{\left(\frac{-\Delta_{T} G^{o} 1473}{R \times 1473}\right)}
$$

where

$$
\begin{aligned}
& \Delta_{T} G^{\circ}{ }_{1473}=\text { Gibbs free energy change }(1473 \mathrm{~K}) \text { for above reaction } \\
& \mathrm{K}_{\mathrm{E}}=\text { equilibrium constant for }(2) \text { and }(3) \text { above at } 1473 \mathrm{~K} \text { (dimensionless) } \\
& \mathrm{a}^{\mathrm{E}}=\text { thermodynamic activity of each component (dimensionless) } \\
& \mathrm{R}=\text { gas constant } \\
& \mathrm{K}=\text { reaction temperature }(1473 \mathrm{~K})
\end{aligned}
$$

The activities of $\mathrm{La}_{2} \mathrm{O}_{3}(\mathrm{~s}), \mathrm{Sm}_{2} \mathrm{O}_{3}(\mathrm{~s})$, and $\mathrm{La}^{\circ}(/)$ are all 1 (pure phase). Putting these values, simplifies equation 2 and 3 to 


$$
K_{E}=\left(a_{S m^{0}(g)}^{E}\right)^{2}=e^{\left(\frac{-\Delta_{T} G^{o} 1473}{R \times 1473}\right)}
$$

or

$$
=e^{\left(\frac{-(+45)}{008314 \times 1473}\right)}=0.025
$$

Square root of both sides yields.

$$
a_{S m^{0}(g)}^{E}=\sqrt{0.025}=0.16
$$

The activity of gases is defined as

$$
a_{S m^{0}(g)}^{E}=\frac{P_{S m^{0}(g)}^{E}}{1}
$$

where

$$
\begin{aligned}
& P_{S m^{0}(g)}^{E}=\text { the equilibrium partial pressure (bar) of } \mathrm{Sm}^{\circ}(\mathrm{g}) \\
& 1=\text { the standard state pressure of pure gas }=10^{5} \text { pascal }
\end{aligned}
$$

Combining equation 6 and 7 ,

Rearranging

$$
a_{S m^{0}(g)}^{E}=\frac{P_{S m^{0}(g)}^{E} b a r}{1 b a r}=0.16
$$

$$
\begin{aligned}
P_{S m^{0}(g)}^{E} b a r & =a_{S m^{0}(g)}^{E} \times 1 \\
& =0.16 \times 1 \mathrm{bar} \\
& =0.16 \mathrm{bar} \\
& =1.6 \times 10^{4} \mathrm{bar}
\end{aligned}
$$

This relatively high samarium pressure indicates that reduction process can proceed quickly under negative pressure (vacuum) of $10^{-3}-10^{-4}$ pascal absolute.

\subsection{Calcium reduction}

Calcium reduction of rare earth fluorides is typified by reaction equation [12].

where

$$
\begin{aligned}
& 1470^{\circ} \mathrm{C}(1743 \mathrm{~K})
\end{aligned}
$$

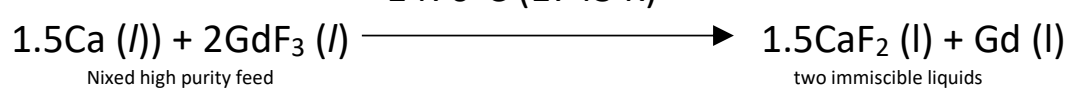

$$
\Delta_{\mathrm{T}} \mathrm{G}^{\circ}{ }_{1743 \mathrm{~K}}=-120 \mathrm{MJ} / \mathrm{kg}-\text { mole of } \mathrm{GdF}_{3}(/)[11]
$$


It is used for producing all low vapor pressure rare earth metals, often in competition with electrowinning [10]. Other metals that may be produced by this method are, $\mathrm{La}, \mathrm{Ce}, \mathrm{Pr}, \mathrm{Nd}, \mathrm{Tb}$, Dy,, Ho, Er, Lu.

\subsubsection{Thermodynamics}

Its thermodynamic treatment is same as above [10]. The equilibrium quantities and Gibbs free energy are related by below equations [11].

and

$$
K_{E}=\frac{\left(a_{C a F_{2}(l)}^{E}\right)^{1.5} x\left(a_{G d^{b}(l)}^{E}\right)}{\left(a_{G d F_{3}(l)}^{E}\right) x\left(a_{C a^{\mathrm{o}}(l)}^{E}\right)^{1.5}}
$$

$$
K_{E}=e^{\left(\frac{-\Delta_{T} G^{o} 1743}{R \times 1743}\right)}
$$

where

$$
\begin{aligned}
& \Delta_{T} G^{\circ}{ }_{1743}=\text { Gibbs free energy change for reaction } 8 \\
& \mathrm{~K}_{\mathrm{E}}=\text { Equilibrium constant for }(8) \text { above at } 1743 \mathrm{~K} \text { (dimensionless) } \\
& \mathrm{a}^{\mathrm{E}}=\text { Thermodynamic activity of each component (dimensionless) } \\
& \mathrm{R}=\text { Gas constant } \\
& \mathrm{K}=\text { Reaction temperature }(1473 \mathrm{~K})
\end{aligned}
$$

\subsection{On set and occurrence of reaction (Relation between free energy and temperature) - Ellingham diagrams}

Selection of suitable reducing agent can be predicted from standard free energy of formation. Reduction occurs if difference of $\Delta \mathrm{G}^{\circ}$ of $\mathrm{Nd}_{2} \mathrm{O}_{3}$ with $\Delta \mathrm{G}^{\circ}$ of $\mathrm{MO}$ is negative. Where $\mathrm{M}=\mathrm{Ca}, \mathrm{La}, \mathrm{Mg}$, $\mathrm{K}, \mathrm{Na}$, Si (in present case, $\mathrm{Ca}$ ). This may be easily determined from plots between free energy $\left(\Delta \mathrm{G}^{\circ}\right)$ and temperature known as Ellingham diagrams [13-15]. 


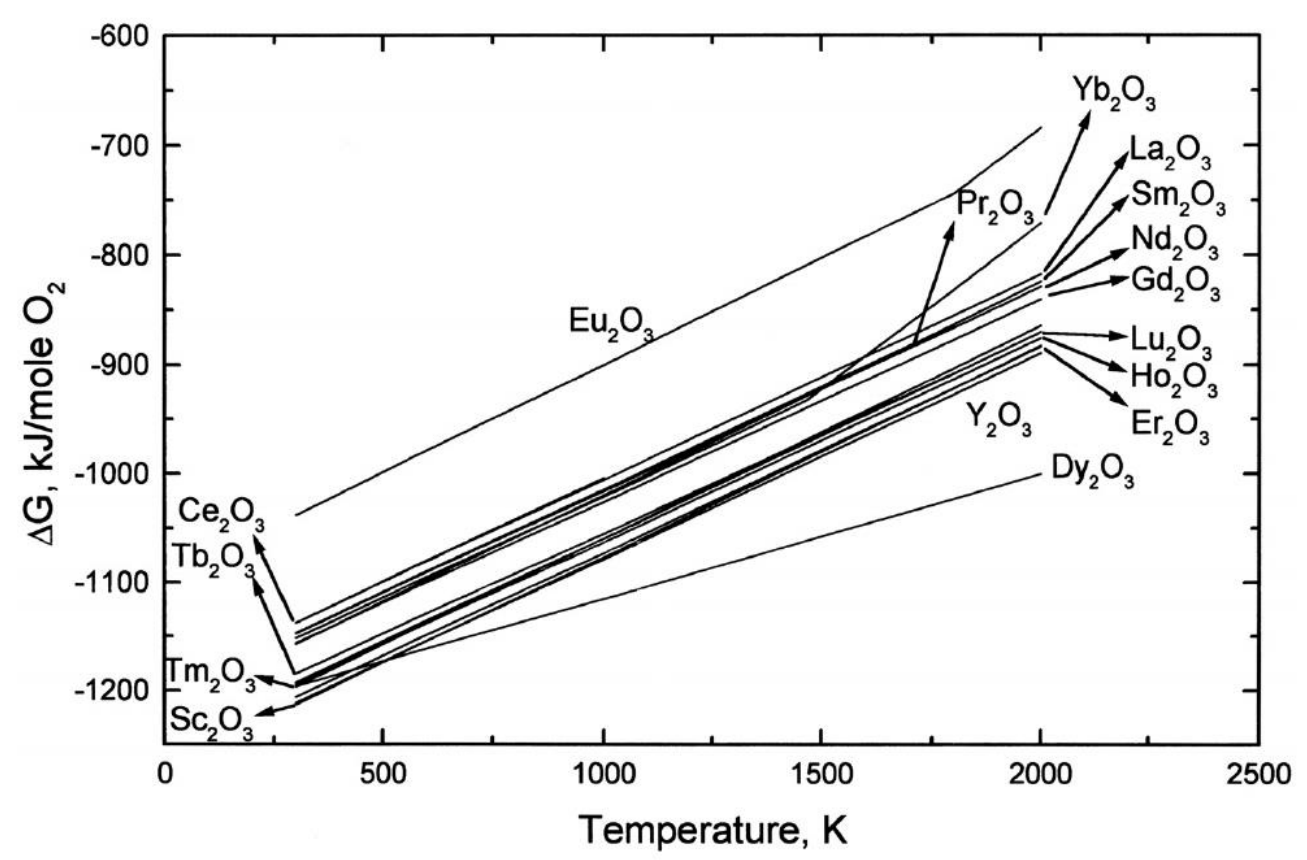

Figure - 1: Standard free energy of formation of rare earth oxides as a function of temperature

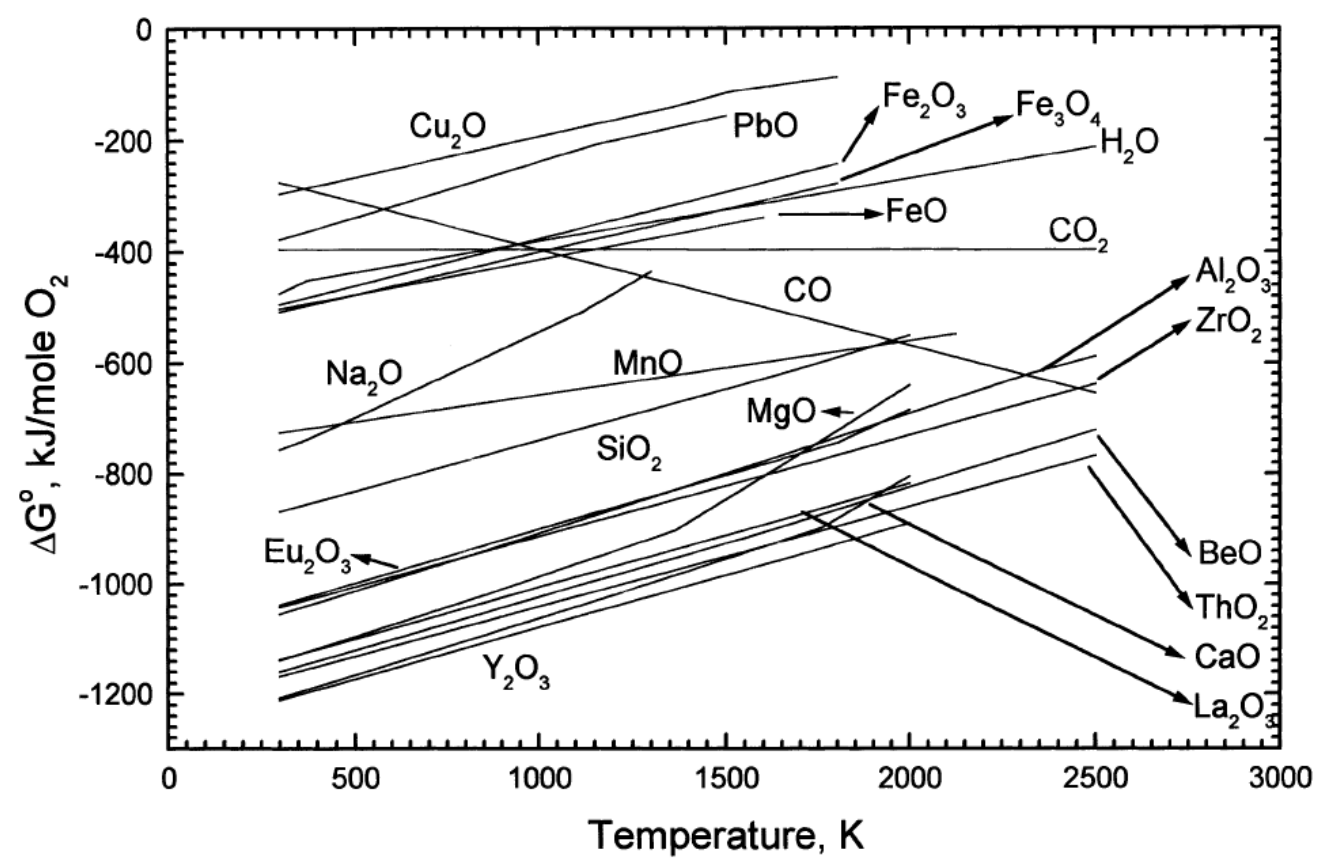

Figure - 2: Standard free energy of formation of selected oxides of rare earths and common metals as a function of temperature. 


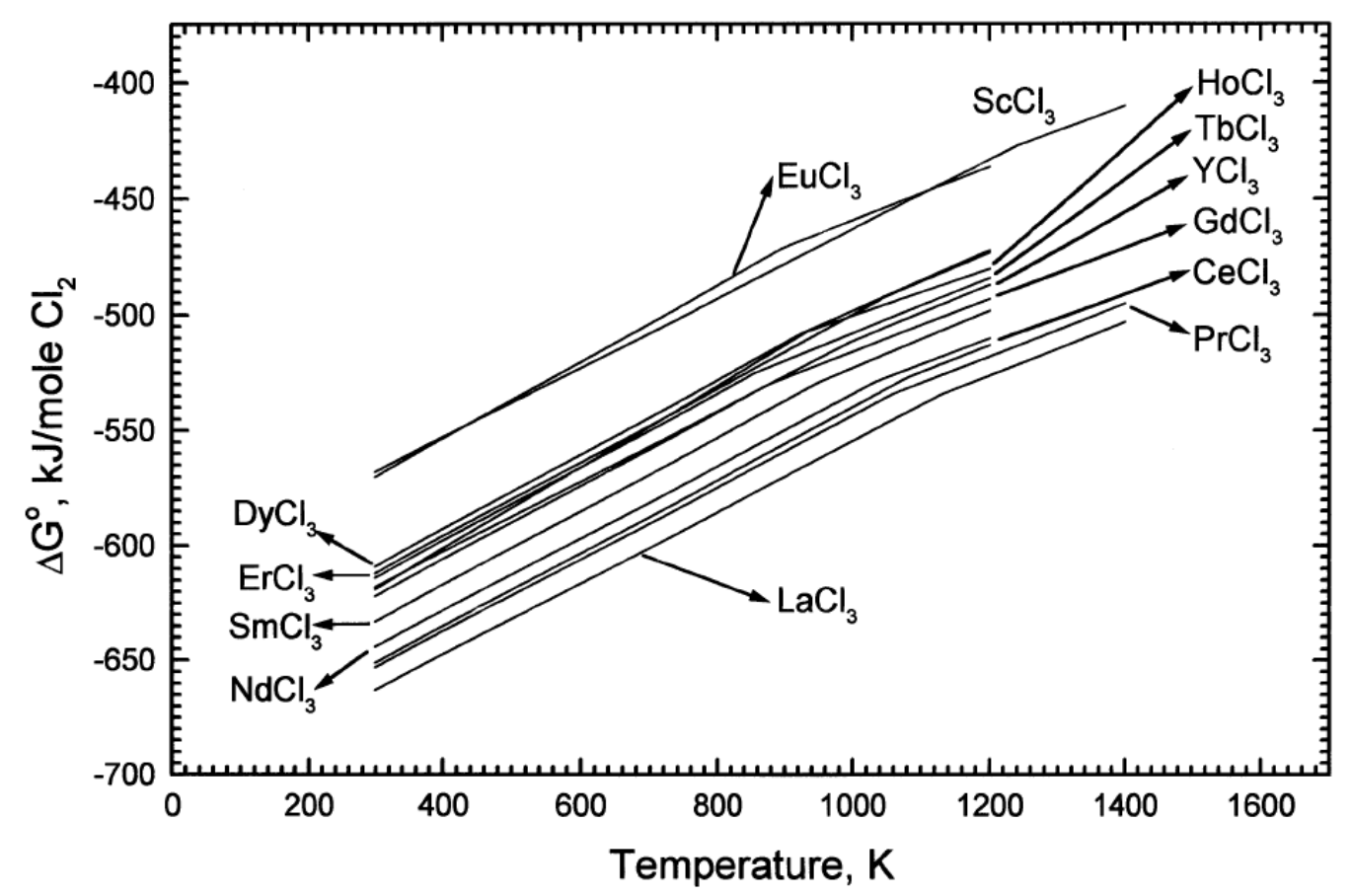

Figure - 3: Standard free energy of formation of rare earths chlorides as a function of temperature

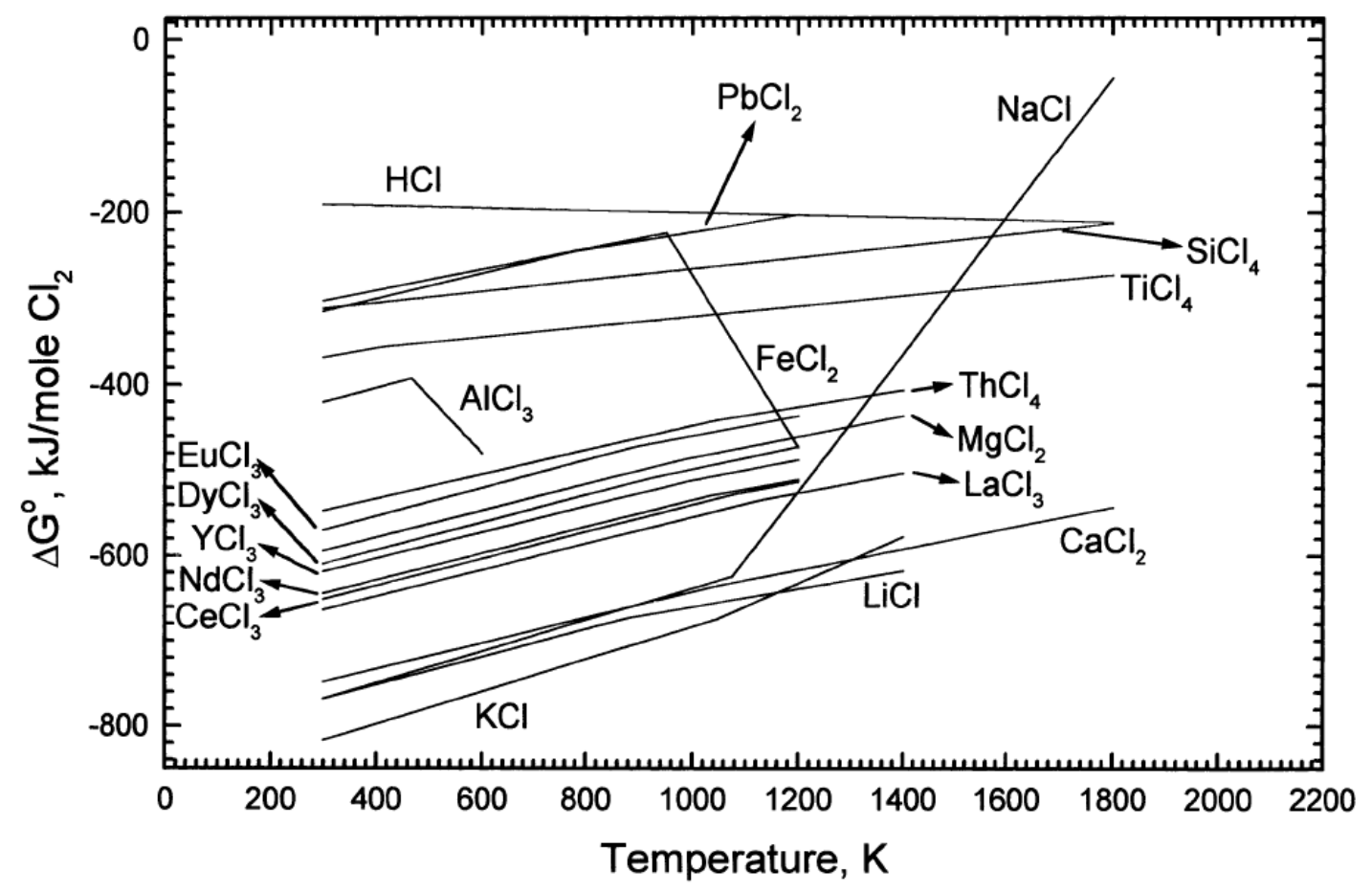

Figure -4: Standard free energy of formation of selected chlorides of rare earths and certain common metals as a function of temperature 
Page 8 of 14

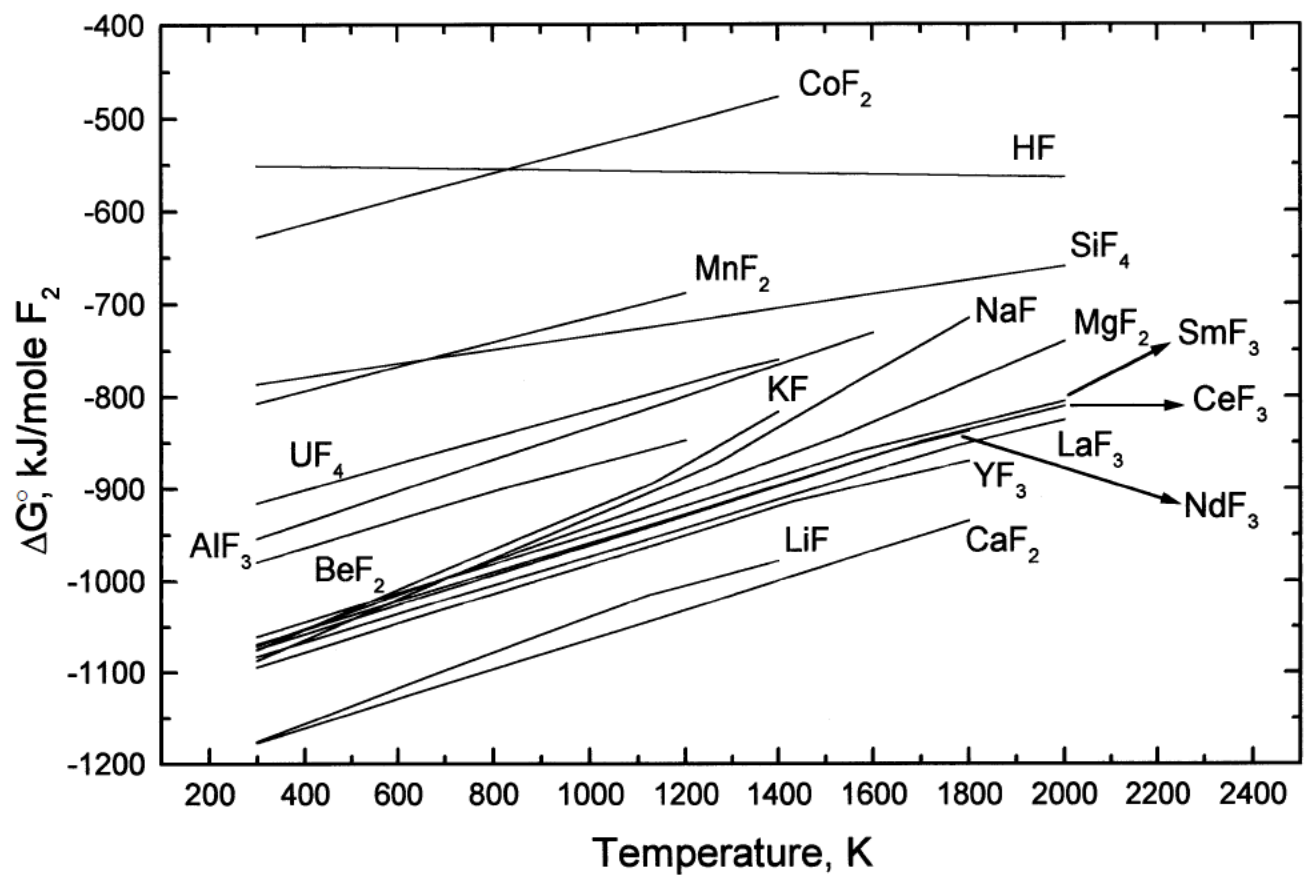

Figure - 5: Standard free energy of formation of selected fluorides of rare earths and certain common metals as a function of temperature

\section{Electrowinning (Electrometallurgy)}

\section{a. Aqueous systems}

Standard free energy of rare earths is calculated from literature [16, 17]. Reactions happening during their formation and corresponding Nernst equations are summarized in table below.

Table 2: Calculated values of $\Delta \mathrm{G}(\mathrm{kJ} / \mathrm{mol})$ and standard reduction potential at $298 \mathrm{~K}$ and the corresponding Nernst equation

\begin{tabular}{|c|c|c|c|}
\hline Reaction & $\Delta G^{\circ}(\mathrm{kJ} / \mathrm{mol})$ & $E^{\circ}(V)$ & Nernst equation \\
\hline $\mathrm{Nd}^{3+}+3 \mathrm{e}^{-} \longleftrightarrow \mathrm{Nd}$ & -671.6 & -2.32 & $E=-2.32+0.020 \log \left[\mathrm{Nd}^{3+}\right]$ \\
\hline $\mathrm{Nd}+3 \mathrm{H}_{2} \mathrm{O} \longleftrightarrow \mathrm{Nd}(\mathrm{OH})_{3}+3 \mathrm{H}^{+}+3 \mathrm{e}^{-}$ & -563.3 & -1.94 & $E=-1.94+0.059 p H$ \\
\hline $\mathrm{Nd}^{3+}+3 \mathrm{H}_{2} \mathrm{O} \longleftrightarrow \mathrm{Nd}(\mathrm{OH})_{3}+3 \mathrm{H}^{+}$ & 108.3 & & $3 \mathrm{pH}=19-\log \left[\mathrm{Nd}^{3+}\right]$ \\
\hline $\mathrm{Dy}^{3+}+3 \mathrm{e}^{-} \longleftrightarrow \mathrm{Dy}$ & -664.0 & -2.29 & $E=-2.29+0.020 \log \left[\mathrm{Nd}^{3+}\right]$ \\
\hline $\mathrm{Dy}+3 \mathrm{H}_{2} \mathrm{O} \longleftrightarrow \mathrm{Dy}(\mathrm{OH})_{3}+3 \mathrm{H}^{+}+3 \mathrm{e}^{-}$ & -564.4 & -1.95 & $E=-1.95+0.059 p H$ \\
\hline $\mathrm{Dy}^{3+}+3 \mathrm{H}_{2} \mathrm{O} \longleftrightarrow \mathrm{Dy}(\mathrm{OH})_{3}+3 \mathrm{H}^{+}$ & 98.6 & & $3 \mathrm{pH}=17.3-\log \left[\mathrm{Dy}^{3+}\right]$ \\
\hline $\mathrm{Pr}^{3+}+3 \mathrm{e}^{-} \longleftrightarrow \mathrm{Pr}$ & -680.3 & -2.35 & $\mathrm{E}=-2.35+0.020 \log \left[\mathrm{Pr}^{3+}\right]$ \\
\hline $\mathrm{Pr}+3 \mathrm{H}_{2} \mathrm{O} \longleftrightarrow \mathrm{Pr}(\mathrm{OH})_{3}+3 \mathrm{H}^{+}+3 \mathrm{e}^{-}$ & -568.0 & -1.96 & $E=-1.96+0.059 p H$ \\
\hline $\mathrm{Pr}^{3+}+3 \mathrm{H}_{2} \mathrm{O} \longleftrightarrow \operatorname{Pr}(\mathrm{OH})_{3}+3 \mathrm{H}^{+}$ & 111.9 & & $3 \mathrm{pH}=19.68-\log \left[\mathrm{Pr}^{3+}\right]$ \\
\hline
\end{tabular}


Their very negative potential values which fall below the hydrogen evolution line indicate a strong reactivity in aqueous solutions. Experimental observation of corrosion and passivity behavior of $\mathrm{Nd}$ in different conditions have also confirmed rigorous hydrogen evolution [18].

In particular, comparison of behavior of iron and REE in aqueous solutions at different pH can be of importance. Pourbaix diagram [19] is used to see stability of different species of $\mathrm{Nd}$ and Fe in different $\mathrm{pH}$ and they selectively leached out $\mathrm{Nd}^{3+}$ by leaving out iron as $\mathrm{Fe}_{2} \mathrm{O}_{3}$ in the solution. In contrast to selective leaching, where $\mathrm{pH}$ plays a vital role, using electrochemical cell offers an additional advantage of controlling parameters like potential and current density to manipulate and selectively dissolve REEs. Below figure shows standard electrode potential of different components of scrap magnets vs $\mathrm{Ag} / \mathrm{AgCl}$ electrode ( $0.25 \mathrm{~V}$ vs $\mathrm{SHE})$. The standard reduction potential of iron and cobalt are $-0.44 \mathrm{~V}$ and $-0.28 \mathrm{~V}$ vs SHE respectively. EOL magnets also contain copper, as a minor additive or in the coating along with $\mathrm{Ni}$ to present oxidation.

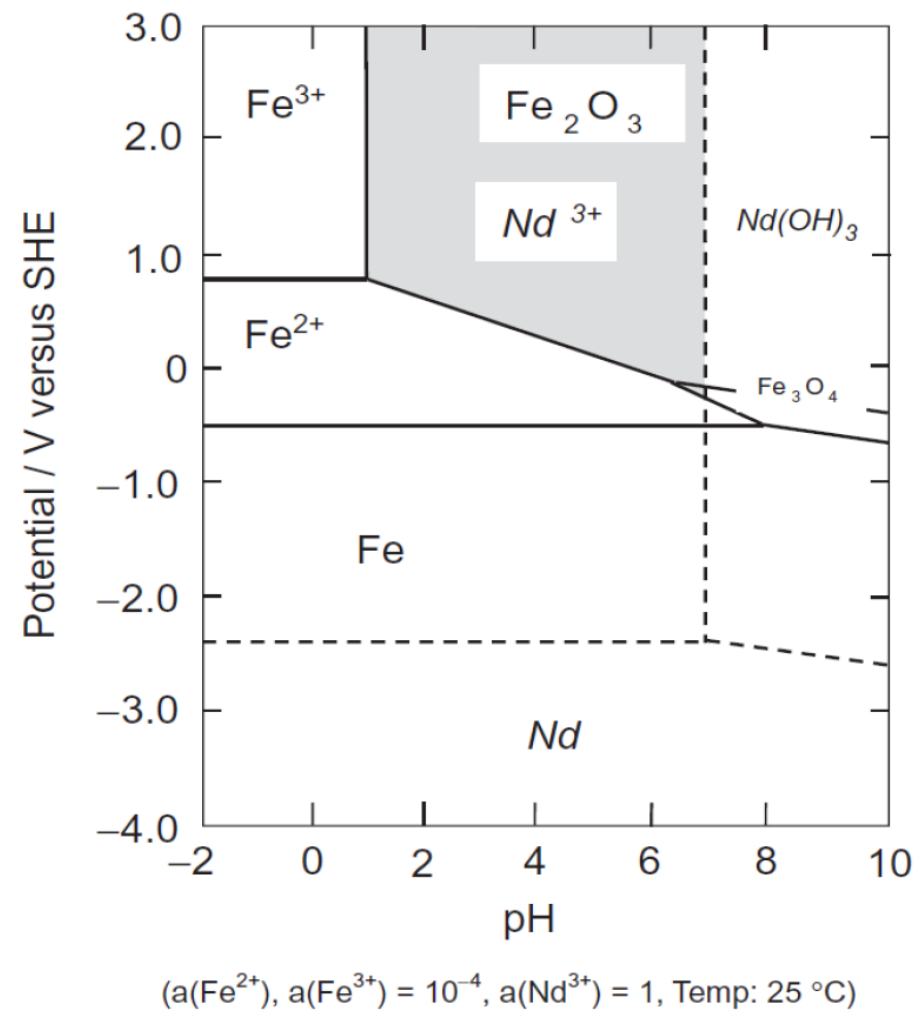

Figure - 6: Pourbaix diagram of $\mathrm{Fe}-\mathrm{H}_{2} \mathrm{O}$ and $\mathrm{Nd}-\mathrm{H}_{2} \mathrm{O}$ system

Electrowinning is usually performed of oxides dissolved in fluorides through which direct current is passed. It can be noted when magnets are deployed as anodes in a 3-electrode electrochemical cell. $(\mathrm{Ag} / \mathrm{AgCl}$ reference electrode), selective dissolution may be accelerated by controlling the potential and maintaining it in the region between dissolution of rare earths and the region in which metallic iron, cobalt and other elements are stable. Further, anodic polarization can accelerate dissolution process. 


\begin{tabular}{|c|c|}
\hline $\left.\mathrm{E}_{(\mathrm{Cu}}^{0}{ }^{2+} / \mathrm{Cu}\right)=0.09$ & $\mathrm{Cu}^{2+}+2 \mathrm{e}^{-} \Leftrightarrow \mathrm{Cu}$ \\
\hline $\mathrm{E}^{0}\left(\mathrm{Co}^{2+} / \mathrm{Co}\right)=-0.54$ & $\mathrm{Co}^{2+}+2 \mathrm{e}^{-} \Leftrightarrow \mathrm{Co}$ \\
\hline $\mathrm{E}_{\left(\mathrm{Ni}^{0} / \mathrm{Ni}\right)}^{2+}=-0.5$ & $\mathrm{Ni}^{2+}+2 \mathrm{e}^{-} \Leftrightarrow \mathrm{Ni}$ \\
\hline $\left.\mathrm{E}_{(\mathrm{Fe}}^{0} / \mathrm{Fe}\right)=-0.65$ & $\mathrm{Fe}^{2+}+2 \mathrm{e}^{-} \Leftrightarrow \mathrm{Fe}$ \\
\hline$E_{(B(O H) 3 / B)}^{0}=-1.14$ & $\mathrm{H}_{3} \mathrm{BO}_{3}+3 \mathrm{H}^{+}+3 \mathrm{e}^{-} \Leftrightarrow \mathrm{B}+3 \mathrm{H}_{2} \mathrm{O}$ \\
\hline $\mathrm{E}_{\left(\mathrm{RE}^{3+} / \mathrm{RE}\right)}=-2.44$ & $\mathrm{RE}^{3+}+3 \mathrm{e}^{-} \Leftrightarrow \mathrm{RE}$ \\
\hline
\end{tabular}

Figure - 7: Standard reduction potential ( $\mathrm{V}$ v $\mathrm{Ag} / \mathrm{AgCl}$ ) of different metals in scrap magnet.

\section{Molten salt electrolysis of rare earth metals}

\subsection{Fused salt}

Fused salt or molten salt is a salt that is solid at ambient temperature and enters the liquid phase at elevated temperature. A molten salt has a low viscosity, high heat capacity and high electrical and thermal conductivity. This electrolyte has been used for some applications like transferring heat in solar tower, as a catalyst in coal gasification, in a molten salt reactor. It can also be used for extracting nonferrous metals such as: aluminum, titanium, and magnesium (in chloride bath) and rare earths by electrolysis. Comparing with molten salts' properties, the aqueous solutions have some limitations in some applications such as (a) can not withstand at high temperature condition, can not transfer heat sufficiently, have a higher energy of formation (less reactive) than rare earth oxides, which makes the reaction unlikely to occur in extracting rare earth oxides. Disadvantages are fused salts are corrosive especially when an oxidant is present and have a volume expansion upon melting of about $25 \%$. These values can cause adverse effect in some application and severely damage the environment. Nevertheless, the ongoing research of thermodynamics, chemistry and electro chemistry of fused salt is still needed so that fused salt technology can fully be understood and developed in future. 
Page 11 of 14

\subsection{Fused salt mixture}

Fused salt is in a solid state at room temperature; therefore, it requires heat to raise the temperature above its melting point to ensure the fused salt remains in the molten state as an electrolyte in the electrolysis process. This is energy extensive process. One good way to overcome this is use of mixture of fused salts at its eutectic point which have lower melting point than both constituents. For example, $\mathrm{KBr}-\mathrm{KF}$. Below is a phase diagram of this system which shows its eutectic point at $40.5 \%$. This system has its melting point of $581^{\circ} \mathrm{C}$ at $40.5 \% \mathrm{KF}$ mole.

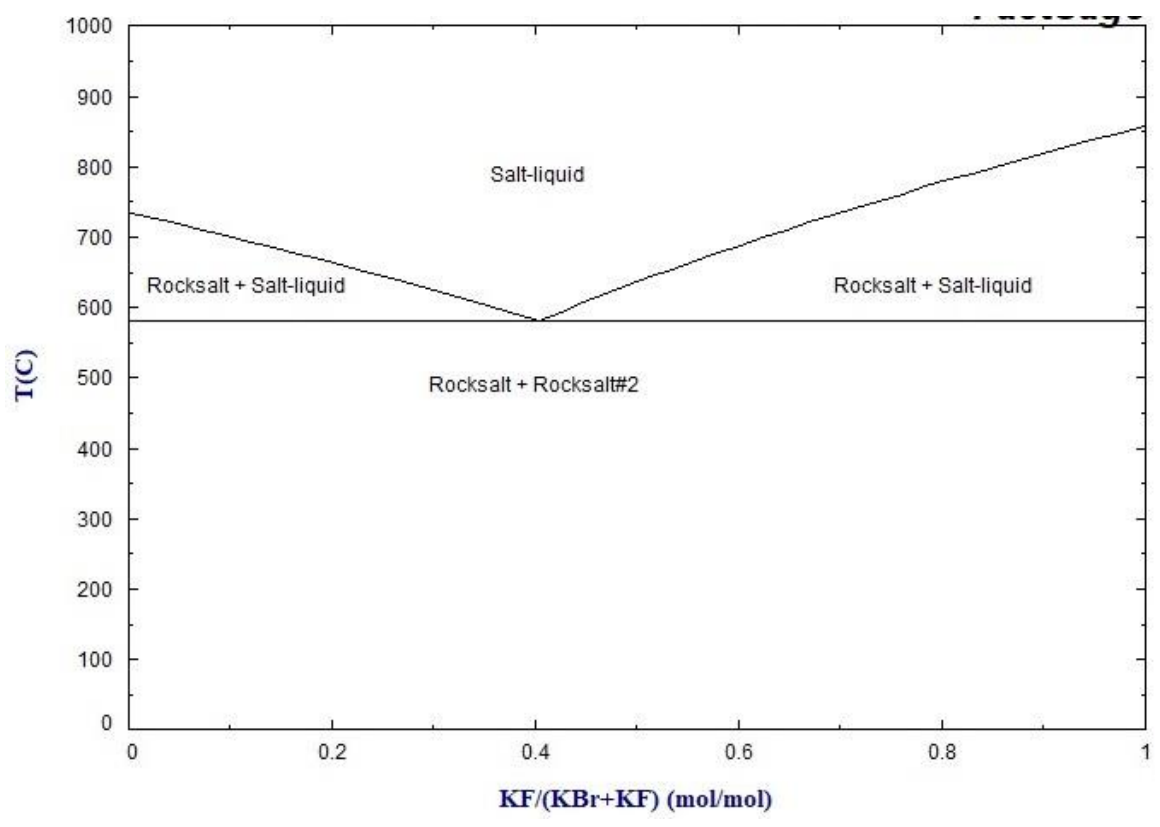

Figure - 8: Phase diagram of $\mathrm{KBr}+\mathrm{KF}$

Similarly, a few types of molten salts such as alkali metal fluoride and rare earth fluoride are effectively used to increase the solubility of rare earth oxide as feed material. In some cases (for example, $\mathrm{KF}-\mathrm{LaF}_{3}$ ), a complex compound or solid compound is formed during extraction which makes the process even more difficult to continue and extract rare earths. This system has melting point at $620^{\circ} \mathrm{C}$ at its eutectic point with 22 mole $\%$ of $\mathrm{LaF}_{3}$. For mole \% age composition $<22 \%$, KF solid is formed at $620^{\circ} \mathrm{C}$ and for mole $\%$ age composition $>22 \%$ at $600^{\circ} \mathrm{C}, \mathrm{KF} . \mathrm{LaF}_{3}$ solid is formed which retards the decomposition of LaRE to La metal in the cathode.

\subsection{Predominance or Potential - oxide ion activity $\left((\mathrm{E})-\mathrm{pO}^{2-}\right)$ diagram for molten salt}

Molten salt electrolysis is similar to electrolysis in aqueous systems. For example, in both processes, current is charged between two electrodes through an ionized medium (molten bath / electrolyte) to deposit metal (typically by reduction of metallic cations) on the cathode and evolve gas (typically by oxidation of anions) on the anode. To predict thermodynamic phase evolution of metal of interest and corrosion resistance, particularly electrode (dissolution rate) 
and materials of construction of cell (for material solution interaction), diagrams known as E $\mathrm{pO}^{2-}$ is used. These were first time introduced in 1960s [20] to predict the conditions that would allow electrolytic production of metal and to investigate its corrosion [21-24] along with electrode and other materials.

Table 1: Comparison between $\mathrm{E}_{\mathrm{H}}-\mathrm{pH}$ and $\mathrm{E}-\mathrm{pO}^{2-}$-diagrams

\begin{tabular}{|c|c|c|c|}
\hline Sr. No. & Parameter & Pourbaix $\left(E_{H}-p H\right)$ & $\begin{array}{c}\text { Predominance or } \\
\text { Potential - oxide ion }(E- \\
\left.\mathrm{pO}^{2-}\right)\end{array}$ \\
\hline 1 & $\begin{array}{l}\text { Working principal based } \\
\text { on potential }\end{array}$ & Increasing & Decreasing \\
\hline 2 & System & Aqueous & Molten or fused salt \\
\hline 3 & Electrochemistry & Independent & $\begin{array}{ll}\text { Highly dependent } & \text { on } \\
\text { medium (molten salt) } & \end{array}$ \\
\hline 4 & Solubility & Water is medium & $\begin{array}{l}\text { independent of particular } \\
\text { molten salt as medium }\end{array}$ \\
\hline 5 & Redox couple & Not required & Required \\
\hline 6 & $\begin{array}{l}\text { Performance as a } \\
\text { function of temperature }\end{array}$ & Constant & Highly varied \\
\hline 7 & $\begin{array}{l}\text { Performance as a } \\
\text { function of composition }\end{array}$ & Invariably constant & Highly varied \\
\hline 8 & $\begin{array}{l}\text { Standard measuring } \\
\text { potential }\end{array}$ & Electrode potential & $\begin{array}{l}\text { Standard } \\
\text { electrode. }\end{array}$ \\
\hline
\end{tabular}

\subsection{Potential (E)-pO2- diagrams for $\mathrm{Nd}$}

Construction of (E)-pO $\mathrm{pO}^{2-}$ diagrams are reported by use of Nernst equation and redox potential in earlier studies detail of which may be found elsewhere [25] and will be presented in subsequent studies. Below figure describes $\mathrm{Nd}$ diagram in $\mathrm{NdF}_{3}-\mathrm{CaF}_{2}-\mathrm{LiF}$ melt including $\mathrm{C}$ as a component (a) with and (b) without the NdOF phase. 
Page 13 of 14
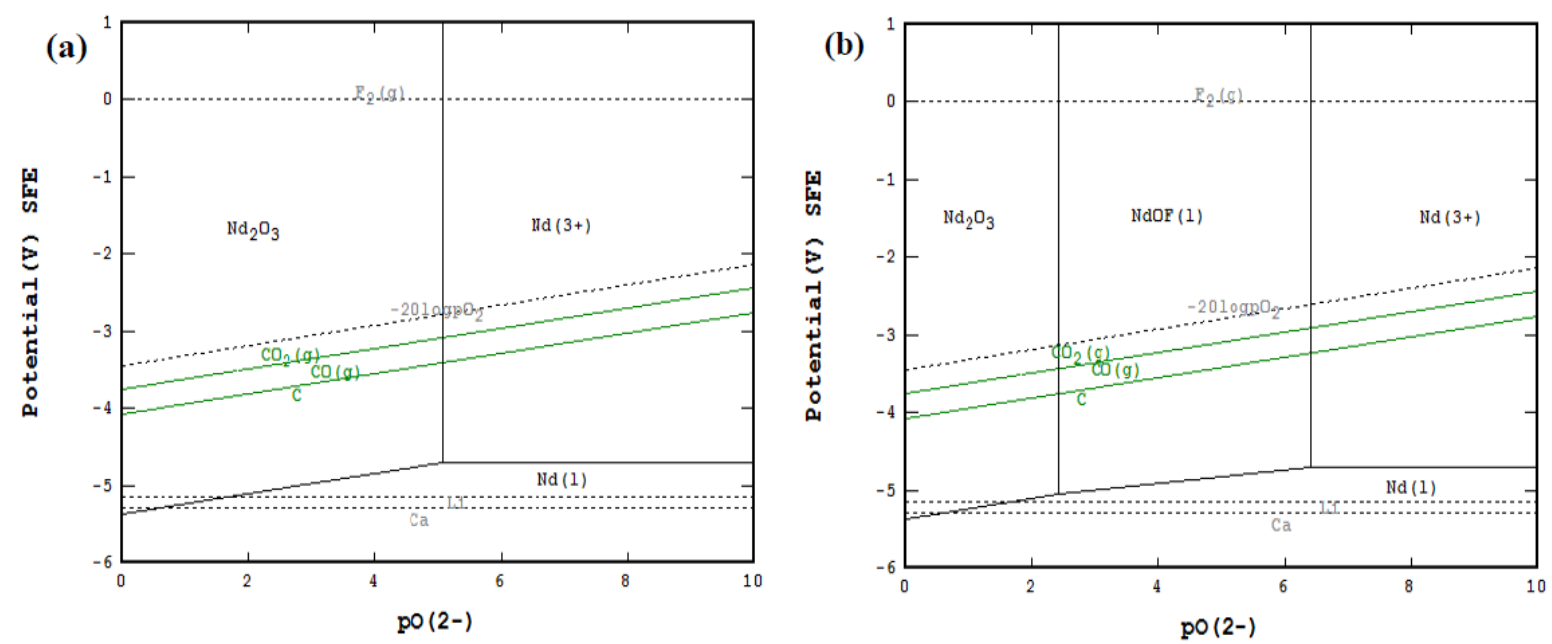

Figure - 9: $\mathrm{E}-\mathrm{pO}^{2-} \mathrm{Nd}$ diagram in $\mathrm{NdF}_{3}-\mathrm{CaF}_{2}-\mathrm{LiF}$ melt including $\mathrm{C}$ as a component (a) with and (b) without the NdOF phase.

\section{Conclusions}

Rare earth elements may be processed by various ways out of which metallothermic reduction and its variant electrowinning are most important. Later may be performed in water (aqueous) or molted salt (fused). Thermodynamics and kinetics of reaction play an important part in ensuring the onset, happening and completion of reaction. Ellingham diagrams for metallothermic reduction and $\mathrm{E}_{\mathrm{h}}-\mathrm{pH}$ and $\mathrm{E}-\mathrm{pO}^{2-}$ diagrams are extensively used to determine reaction at every stage in electrowinning. Their determination for each and individual type of salt used, and its reaction sequence is very important in electrometallurgical extraction of rare earth metals. Combined with Nernst equation and redox potential, it gives measure of activity of reaction and quantification of extraction of certain element of out its oxide or salt.

\section{References}

1. Seredin, V.V. and S. Dai, Coal deposits as potential alternative sources for lanthanides and yttrium. International Journal of Coal Geology, 2012. 94: p. 67-93.

2. Dai, S., et al., Mineralogy and geochemistry of boehmite-rich coals: New insights from the Haerwusu Surface Mine, Jungar Coalfield, Inner Mongolia, China. International Journal of Coal Geology, 2008. 74(3): p. 185-202.

3. Eskenazy, G.M., Rare earth elements in a sampled coal from the Pirin deposit, Bulgaria. International Journal of Coal Geology, 1987. 7(3): p. 301-314.

4. Moldoveanu, G.A. and V.G. Papangelakis, Recovery of rare earth elements adsorbed on clay minerals: I. Desorption mechanism. Hydrometallurgy, 2012. 117-118: p. 71-78.

5. Moldoveanu, G.A. and V.G. Papangelakis, Recovery of rare earth elements adsorbed on clay minerals: II. Leaching with ammonium sulfate. Hydrometallurgy, 2013. 131-132: p. 158-166. 
6. Seredin, V.V., Rare earth element-bearing coals from the Russian Far East deposits. International Journal of Coal Geology, 1996. 30(1): p. 101-129.

7. Sui, N., et al., Light, Middle, and Heavy Rare-Earth Group Separation: A New Approach via a LiquidLiquid-Liquid Three-Phase System. Industrial \& Engineering Chemistry Research, 2013. 52(17): p. 5997-6008.

8. Gupta, C.K. and N. Krishnamurthy, Extractive metallurgy of rare earths. International Materials Reviews, 1992. 37(1): p. 197-248.

9. Habashi, F., Extractive metallurgy of rare earths. Canadian Metallurgical Quarterly, 2013. 52(3): p. 224-233.

10. Front matter, in Rare Earths, J. Lucas, et al., Editors. 2015, Elsevier: Amsterdam. p. i-ii.

11. Frontmatter, in Thermochemical Data of Pure Substances. 1995. p. I-L.

12. Rodliyah, I., et al., THERMODYNAMIC SIMULATION AND VALIDATION EXPERIMENT OF NEODYMIUM OXIDE REDUCTION INTO METALLIC NEODYMIUM BY METALLOTHERMIC PROCESS. Indonesian Mining Journal, 2018. 21(1): p. 21-34.

13. Transactions and Communications. Journal of the Society of Chemical Industry, 1944. 63(5): $p$. 125-160.

14. Ellingham, H.J.T., Reducibility of oxides and sulphides in metallurgical processes. Journal of the Society of Chemical Industry, 1944. 63(5): p. 125-133.

15. Richardson, F., The Thermodynamics of Substances of Interest in Iron and Steel Making from $0^{\circ} \mathrm{C}$ to $2400^{\circ} \mathrm{Cl}$-Oxides. J Iron Steel Inst, 1948. 160: p. 261-270.

16. Schweitzer, G.K. and L.L. Pesterfield, The Aqueous Chemistry of the Elements. 2010: Oxford University Press.

17. Bard, A.J., Standard Potentials in Aqueous Solution. 2017: CRC Press.

18. Sueptitz, R., et al., Corrosion, passivation and breakdown of passivity of neodymium. Corrosion Science, 2010. 52(3): p. 886-891.

19. Takeda, O. and T.H. Okabe, Current Status on Resource and Recycling Technology for Rare Earths. Metallurgical and Materials Transactions E, 2014. 1(2): p. 160-173.

20. Edeleanu, C. and R. Littlewood, Thermodynamics of corrosion in fused chlorides. Electrochimica Acta, 1960. 3(3): p. 195-207.

21. Rotter, V.S., P. Chancerel, and M. Ueberschaar, Recycling-Oriented Product Characterization for Electric and Electronic Equipment as a Tool to Enable Recycling of Critical Metals, in REWAS 2013. 2013. p. 192-201.

22. Dring, K., R. Dashwood, and D. Inman, Predominance Diagrams for Electrochemical Reduction of Titanium Oxides in Molten CaCl[sub 2]. Journal of The Electrochemical Society, 2005. 152(10): p. D184.

23. Mansfeld, F. and U. Bertocci. Electrochemical corrosion testing (symposium), 1979. 1981. United States: American Society of Testing Materials,Philadelphia, PA.

24. Jiao, S. and H. Zhu, An investigation into the electrochemical recovery of rare earth ions in a CsClbased molten salt. Journal of Hazardous Materials, 2011. 189(3): p. 821-826.

25. Sarfo, P., Recovery of Rare Earth Elements by Advanced Processing Technologies. 2019. 